Gonella S, Canzan F, Larghero E, Ambrosi E, Palese A, Dimonte V. Hospital volunteering experiences suggest that new policies are needed to promote their integration in daily care: findings from a qualitative study. Zdr Varst. 2019;58(4):164-172. doi: 10.2478/sjph-2019-0021.

\title{
HOSPITAL VOLUNTEERING EXPERIENCES SUGGEST THAT NEW POLICIES ARE NEEDED TO PROMOTE THEIR INTEGRATION IN DAILY CARE: FINDINGS FROM A QUALITATIVE STUDY
}

\author{
IZKUŠNJE V ZVEZI Z OPRAVLJANJEM PROSTOVOLJNEGA DELA \\ V BOLNIŠNICAH NAKAZUJEJO, DA SO POTREBNE NOVE POLITIKE \\ ZA PROMOCIJO VKLJUČEVANJA TEH IZKUŠENJ V DNEVNO OSKRBO: \\ REZULTATI KVALITATIVNE ŠTUDIJE
}

\author{
Silvia GONELLA ${ }^{1}$, Federica CANZAN ${ }^{2}$, Enrico LARGHERO ${ }^{3}$, \\ Elisa AMBROSI ${ }^{4}$, Alvisa PALESE ${ }^{*}$, Valerio DIMONTE ${ }^{6}$
}

\begin{abstract}
${ }^{1}$ Azienda Ospedaliero Universitaria Città della Salute e della Scienza di Torino, Corso Bramante 88-90, 10126 Torino, Italy ${ }^{2}$ University of Verona, Italy

${ }^{3}$ Facoltà Teologica dell'Italia Settentrionale - Sezione Parallela di Torino, Via XX Settembre 83, 10122 Torino, Italy ${ }^{4}$ University of Bologna, Italy 5Universita degli Studi di Udine, Diportimento di Area Medica, Viale Colugna, 33100 Udine, Italy ${ }^{6}$ Dipartimento di Scienze della Sanità Pubblica e Pediatriche, Università degli Studi di Torino, Italy
\end{abstract}

\section{ABSTRACT \\ Keywords: \\ health and social care, health human resources policy, hospital resources, Italy, qualitative methodologies, volunteers}

\section{IZVLEČEK}

Ključne besede:
zdravstvena in
socialna oskrba,
politika človeških
virov v zdravstvu,
bolnišnična sredstva,
Italija, kvalitativne
metodologije,
prostovoljci
prostovoljci
Objective: To explore Hospital Volunteers' (HVs) motivations and experiences, as well as the strategies they adopt to overcome challenging situations during volunteering and the needs they perceive.

Methods: Eleven Italian HVs were purposively approached between January and July 2016, using face-to-face semi-structured interviews. The interviews were audio-recorded, transcribed verbatim and analysed using the descriptive phenomenological approach.

Results: Hospital volunteering emerged as a complex experience characterised by five themes: (a) becoming a volunteer; (b) developing skills; (c) experiencing conflicting emotions; (d) overcoming role difficulties by enacting different resources and strategies; and (e) addressing emerging needs.

Conclusions: According to the findings, hospital policies aimed at promoting volunteer integration in daily care are needed and should be based on (a) a shared vision between the hospital and the volunteer associations regarding the HVs' role and skills; (b) the development of integrated models of care combining different workforces (i.e. professionals and volunteer staff); (c) appropriate training of HVs at baseline; (d) individualised continuous education pathways aimed at supporting HVs both emotionally and in the development of the required skills; and (e) tailored education that is directed to health-care staff aimed at helping them to value the service provided by HVs.

Cilj: Raziskovanje motivacije in izkušenj prostovoljcev v bolnišnicah (prostovoljci) ter strategij, ki jih uporabijo za obvladovanje zahtevnih situacij med samim opravljanjem prostovoljnega dela ter potreb, ki jih zaznajo.

Metode: Med januarjem in julijem leta 2016 je enajst italijanskih prostovoljcev osebno opravljalo namenske polstrukturirane intervjuje. Intervjuji so bili zvočno posneti, dobesedno prepisani in analizirani z uporabo opisnega fenomenološkega pristopa.

Rezultati: Opravljanje prostovoljnega dela v bolnišnicah se je izkazalo kot kompleksna izkušnja, opisana s petimi tematikami: a) pristop $k$ prostovoljstvu, b) razvijanje sposobnosti, c) doživljanje nasprotujočih si občutkov, d) premagovanje težav, ki jih prinese ta vloga, $z$ uporabo različnih virov in strategij in e) naslavljanje nastajajočih potreb.

Zaključki: Glede na rezultate so bolnišnične politike, usmerjene $v$ promocijo vključevanja prostovoljstva $\checkmark$ dnevno oskrbo, potrebne in jih je treba osnovati na podlagi a) skupne vizije med bolnišnico in zvezami prostovoljcev glede vloge in sposobnosti prostovoljcev, b) razvoja integriranega modela oskrbe s povezovanjem različnih delovnih sil (tj. strokovno in prostovoljno osebje), c) ustreznega usposabljanja prostovoljcev $v$ samem izhodišču, d) individualiziranih stalnih izobraževalnih poti, usmerjenih $v$ podpiranje prostovoljcev na čustvenem področju in pri razvoju zahtevanih sposobnosti, in e) izobrazbe po meri, ki je prav tako usmerjena $v$ zdravstveno osebje za pomoč pri vrednotenju storitev, ki jih omogočajo prostovoljci. 


\section{INTRODUCTION}

Hospital volunteering has increased exponentially over the last three decades throughout the world (1). Three million volunteers have recently been documented across England (2) and almost 45,000 volunteer associations in Italy, half of which deliver services in the health and social care sectors (3). In the hospital care sector, different new technical roles (4) and volunteers as staff extenders have started to be considered as an important part of the process of care e.g. in ensuring one-on-one supervision to prevent falls (5), assisting at mealtimes (6), because of increased patients' needs and workload intensity, and limited availability of health-care and family resources (7).

To date, Hospital Volunteers (HVs) perform a variety of different tasks, supporting unaccompanied patients, administering patient surveys, and helping at mealtimes $(6,8,9)$. HVs also perform activities aimed at improving psychological well-being (10). They engage patients in conversation and activities, such as music and art, both documented as being valuable for patients and healthcare professionals $(8,13,14)$.

A recent report exploring volunteering in acute English trusts estimated that every pound invested in the training and management of HVs yielded 11 pounds-worth of services in return (15). Moreover, trained HVs have allowed hospitals to save money by reducing the time staff spend performing basic care (16) and decreased 30 day readmissions among patients with congestive heart failure by improving patients' dietary and medicationrelated education (17). In addition, volunteers bring values that balance the traditional dominance of healthcare professionals and limit excessive medicalization (18). Alongside the well-documented positive impact of HVs, criticism regarding their involvement in regards to patient safety and quality of care has been recently highlighted (19). Volunteers have become the second staff in some hospitals, nursing homes and community settings, similar to that composed of health-care professionals; therefore, it has been suggested that data on their experiences and difficulties should be taken into consideration in the development of policies aimed at improving their role (2). Available studies $(10,21,22)$ have highlighted difficulties in retaining volunteers, thus increasing training costs. However, available evidence has mainly focused on end of life (EOL) care $(10,23,24)$. With the aim of informing appropriate policies concerning recruitment, retention and evaluation of HVs, a study exploring HV motivations and experiences, as well as the strategies they adopt to overcome challenging situations during volunteering and HVs' needs, was performed.
The aim was to explore HVs motivations and experiences, as well as the strategies they adopt to overcome challenging situations during volunteering and the needs they perceive. Specific research questions were the following: (a) What motivations drive HVs to pursue hospital volunteering? (b) What are the HVs' experiences of their hospital volunteering? and (c) What strategies do HVs employ to overcome challenges during hospital volunteering?

\section{METHODS}

\subsection{Design}

A descriptive phenomenological study design was performed between January and July 2016 and is reported here in accordance with the Consolidated criteria for REporting Qualitative research (COREQ) guidelines (25).

\subsection{Participants}

A purposeful sample of volunteers of the Italian Hospital Volunteer Association (AVO) $(26,27)$ was selected based on the following inclusion criteria: volunteers (a) older than 18 years old; (b) volunteering in different hospitals, wards and long-term facilities; (c) with at least one year of experience in the volunteering association; (d) spending at least three hours per week doing volunteer work; (e) capable of communicating in the Italian language; and (f) willing to be interviewed. All volunteers consecutively approached agreed to participate.

\subsection{Data Collection Process}

In a first step, the interview guide (available from the Authors) was developed on the basis of previous studies in the field $(10,22,23)$. This guide was piloted by conducting one interview, not included in this final report, aimed at evaluating its feasibility and understandability: no changes were required. The interview guide was then used as the basis of the face-to-face semi-structured interviews.

Interviews continued until saturation of data, as judged independently by two researchers, which occurred after 11 interviews. The same researcher (SG), a female nurse with previous volunteering experience in social and health care, and with advanced education in nursing, conducted all the interviews. She received training (28) in conducting interviews, which were audio-recorded after having collected the participants' informed consent. All interviews took place in one of the researcher's offices. Only the interviewer and participant were present at the time of interview; the interviewer and the participants met for the first time at the interview. 


\subsection{Data Analysis}

The same researcher (SG) first listened to the recorded interviews several times and then transcribed them verbatim after each meeting (27). Data were then analysed using a descriptive qualitative approach (29) by performing the following steps: 1) Familiarization: all transcripts were read carefully and repeatedly to obtain a general sense of the content 2) Compilation: members of the research team independently examined each transcript line-by-line, using an open coding approach whereby the most significant words and phrases (units of meaning) were highlighted and recorded in the margins of the transcript; 3 ) Condensing: the researchers reduced each significant element to a descriptive label (code): the whole context was considered when condensing and labelling meaningful units with codes; 4) Categorization: the researchers compared the labels and grouped them into categories according to their similarities (categories); and 5) Theming: homogeneous categories were gathered into themes (themes). The transcripts were anonymised and representative quotations from the transcribed text were referred to using the interview (I) number (e.g. I2).

\subsection{Ethical Issues}

According to the Italian law, where no Ethical Authorization is required for studies not concerning patient's data, on a preliminarily fashion, the President and the members of the board of the AVO associated were contacted and the research protocol was presented. Then, they approved the study (communication available from the corresponding Author, December 18th 2015). All participants gave their informed oral consent to participate; confidentiality and anonymity were guaranteed throughout.

\section{RESULTS}

\subsection{Participants}

Overall, four males and seven females were approached, all between the ages of 23 and 72 years. Most of the interviewees were unmarried, and only two participants indicated that their parents had volunteered. Four participants were retired, while six were employed, and one was a student; the majority were educated to high school levels. Participants have reported an average of four years of experience (range 1.5-18 years) as HVs in different settings (e.g. medical, surgical units) according to their personal preferences and attitudes (Table 1).

Table 1. Socio-demographic characteristics of participants.

\begin{tabular}{|c|c|c|c|c|c|c|c|c|c|c|}
\hline $\begin{array}{l}\text { Interview } \\
\text { number }\end{array}$ & Gender & $\begin{array}{l}\text { Age, } \\
\text { years }\end{array}$ & Education & $\begin{array}{l}\text { Marital } \\
\text { status }\end{array}$ & $\begin{array}{l}\text { Work } \\
\text { status }\end{array}$ & $\begin{array}{l}\text { Religiousness/ } \\
\text { Spirituality }\end{array}$ & $\begin{array}{l}\text { Volunteering } \\
\text { example(s) } \\
\text { in family }\end{array}$ & $\begin{array}{l}\text { Overall } \\
\text { volunteering } \\
\text { experience, } \\
\text { years }\end{array}$ & $\begin{array}{l}\text { Experience } \\
\text { in AVO, } \\
\text { years }\end{array}$ & $\begin{array}{l}\text { Hospital } \\
\text { volunteering } \\
\text { setting }\end{array}$ \\
\hline $\mid 1$ & $\mathrm{~F}$ & 72 & $\begin{array}{l}\text { Secondary } \\
\text { school }\end{array}$ & Married & Retired & $\begin{array}{l}\text { Practising } \\
\text { Christian }\end{array}$ & No & 45 & 9 & $\begin{array}{l}\text { Medical } \\
\text { department }\end{array}$ \\
\hline 12 & $M$ & 55 & $\begin{array}{l}\text { Middle } \\
\text { school }\end{array}$ & Married & Retired & $\begin{array}{l}\text { Non-practising } \\
\text { Christian }\end{array}$ & No & 4 & 4 & $\begin{array}{l}\text { Surgical and paediatric } \\
\text { care departments }\end{array}$ \\
\hline 13 & $\mathrm{~F}$ & 68 & $\begin{array}{l}\text { Secondary } \\
\text { school }\end{array}$ & Widowed & Retired & $\begin{array}{l}\text { Practising } \\
\text { Christian }\end{array}$ & No & 20 & 12.5 & $\begin{array}{l}\text { Medical } \\
\text { department }\end{array}$ \\
\hline 14 & $\mathrm{~F}$ & 54 & $\begin{array}{l}\text { Middle } \\
\text { school }\end{array}$ & Married & Housekeeper & $\begin{array}{l}\text { Non-practising } \\
\text { Christian }\end{array}$ & No & 14 & 14 & $\begin{array}{l}\text { Emergency and } \\
\text { surgical departments }\end{array}$ \\
\hline 15 & $M$ & 49 & $\begin{array}{l}\text { Secondary } \\
\text { school }\end{array}$ & Single & Worker & $\begin{array}{l}\text { Non-practising } \\
\text { Christian }\end{array}$ & No & 22 & 18 & $\begin{array}{l}\text { Medical and oncologic } \\
\text { departments }\end{array}$ \\
\hline 16 & $\mathrm{~F}$ & 67 & $\begin{array}{l}\text { Middle } \\
\text { school }\end{array}$ & Married & Retired & $\begin{array}{l}\text { Practising } \\
\text { Christian }\end{array}$ & No & 7 & 6.5 & $\begin{array}{l}\text { Medical and oncologic } \\
\text { departments }\end{array}$ \\
\hline 17 & $\mathrm{~F}$ & 44 & Degree & Single & Office worker & $\begin{array}{l}\text { Practising } \\
\text { Christian }\end{array}$ & No & 5 & 1.5 & $\begin{array}{l}\text { Medical } \\
\text { department }\end{array}$ \\
\hline 18 & $M$ & 29 & Degree & Single & Estate agent & Agnostic & No & 3 & 3 & $\begin{array}{l}\text { Long-term } \\
\text { facilities }\end{array}$ \\
\hline 19 & $\mathrm{~F}$ & 23 & $\begin{array}{l}\text { Secondary } \\
\text { school }\end{array}$ & Single & Educator & $\begin{array}{l}\text { Practising } \\
\text { Christian }\end{array}$ & $\begin{array}{l}\text { Yes (mother } \\
\text { and uncle) }\end{array}$ & 4 & 3.5 & Spinal unit \\
\hline 10 & $\mathrm{~F}$ & 54 & $\begin{array}{l}\text { Middle } \\
\text { school }\end{array}$ & Divorced & Office worker & $\begin{array}{l}\text { Non-practising } \\
\text { Christian }\end{array}$ & Yes (father) & 8 & 2 & $\begin{array}{l}\text { Surgical and paediatric } \\
\text { departments }\end{array}$ \\
\hline 11 & $M$ & 29 & $\begin{array}{l}\text { Secondary } \\
\text { school }\end{array}$ & Single & Office worker & Atheist & No & 2.5 & 2.5 & $\begin{array}{l}\text { Emergency } \\
\text { department }\end{array}$ \\
\hline
\end{tabular}

Abbreviations: AVO, Hospital Volunteer Association; F, Female; I1, Interview n. 1; M, Male. 


\subsection{The Experience of Hospital Volunteers}

Hospital volunteering emerged as a complex experience that was described by 70 codes gathered into 18 categories and, in turn, into five themes (Figure 1).

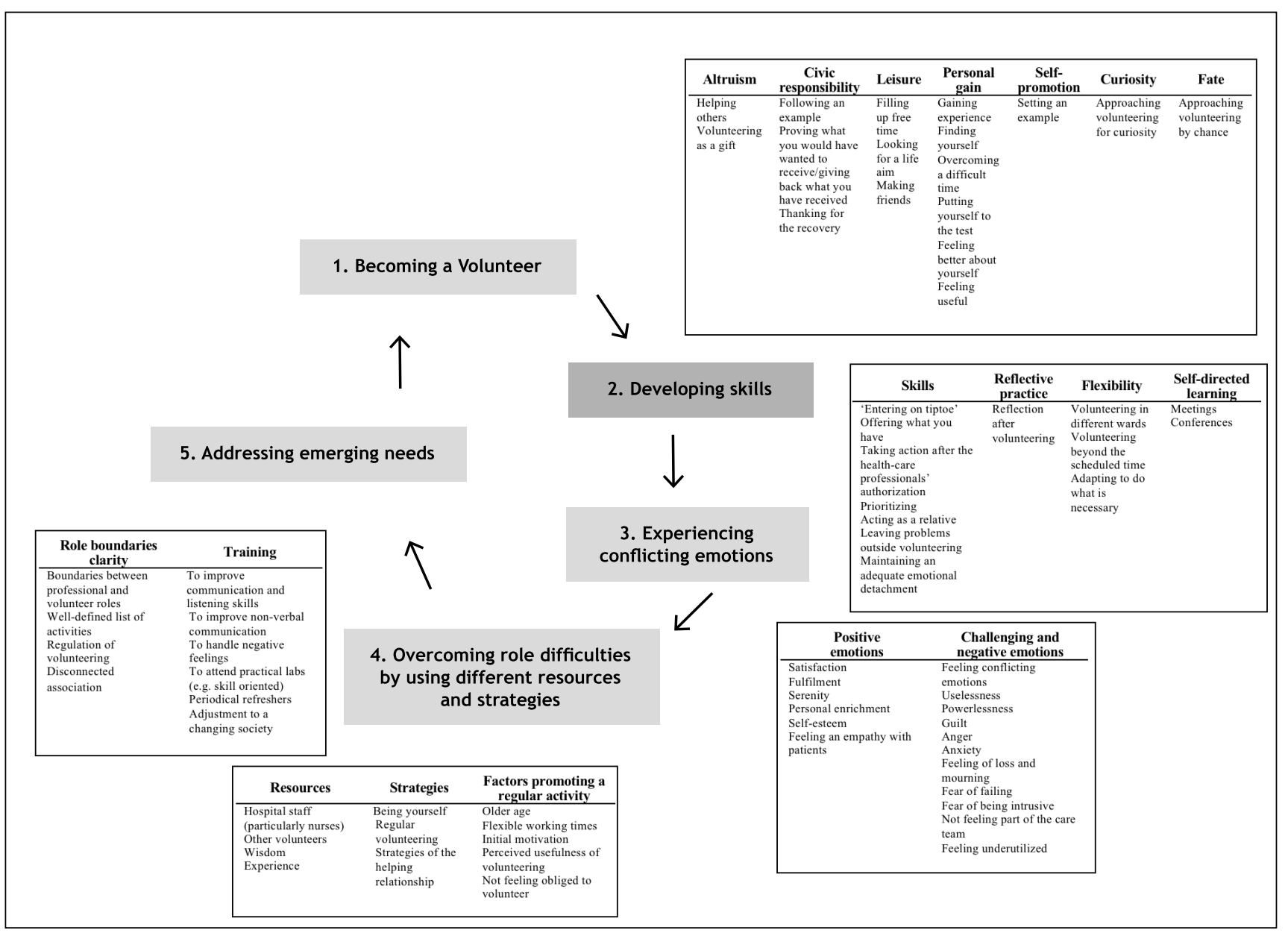

Figure 1. Themes, categories and codes as emerged from narratives.

\section{Theme 1: Becoming a volunteer}

The participants reported becoming a HV for different reasons. 'Helping others' was the main reason for volunteering; however, for the interviewees to continue to feel motivated, it was also important for them to feel that they were benefiting from the experience. Gains from volunteering were expressed in terms of 'gaining experience', 'making friends' and 'overcoming a difficult time'. Other participants mentioned psychological gains, such as 'finding yourself', 'feeling useful' and 'feeling better about yourself'. Some interviewees have also reported that they volunteered to 'kill time' or because they were 'looking for a purpose in life':
'Volunteering is a form of selfishness because when I stopped working, I felt lost. I had no more tangible goals and so I decided to help others' (I 3).

The motivations of 'being thankful for recovery' and 'giving something back or giving what you would have wanted to receive' were linked to having experienced a disease:

'When I was admitted to hospital, I was alone; I didn't know anyone [...]. I felt lonely [...]. In brief, I like to do what I would have wished for myself at the time' (I 4).

Some participants felt the responsibility to 'provide or follow an example', while two mentioned 'curiosity' about what a volunteer could do or simply 'fate' as a motivating factor. 


\section{Theme 2: Developing skills}

Participants have reported many skills and personal attributes that they considered essential as HVs. 'Entering on tiptoe' was the attribute most frequently reported. Volunteers tried to 'not disturb', 'not meddle', 'not interfere', 'keep your own place', 'not be a substitute' and 'withdraw when relatives are there/are present'. Volunteers should provide 'something different' compared to health staff and family relatives, by 'offering what you have' and by 'providing moral support for the patient'.

Emotional detachment and maintaining an adequate barrier to avoid emotional involvement have been highlighted as important skills. Simultaneously, they have reported a need to leave their personal problems outside of volunteering:

'Proper detachment does not mean being cold, but it means maintaining the right distance to avoid emotional involvement since some stories really make you think'. (I 5).

Several participants have reported that volunteers are asked to prioritize their tasks. Moreover, they often act in behalf of relatives when performing small services and take action only after authorization from medical staff if tasks go beyond what is regulated by the association. Therefore, there is the need to recognize when the task requires appropriate authorization:

'In theory, we could not feed. However, we can help with this activity with staff indication if they determine there is no danger as it is a necessity' (I).

They have reported that volunteers have the responsibility to update their skills to be ready to manage difficult situations and increase their performance. They have also emphasized the flexible nature of volunteering that requires self-reflection and self-directed learning: volunteering in different wards, prolonging their activities beyond scheduled time when their presence is required, and 'adapting to do what is necessary', have been reported as examples of flexibility.

\section{Theme 3: Experiencing conflicting emotions}

Participants have often reported feeling conflicting emotions because of the varied situations they experienced. Most of these emotions were positive, such as serenity, satisfaction, fulfilment 'for having relieved a burden'. Some reported feeling personal enrichment, which was mostly derived from sharing patients' life experiences. Moreover, others have mentioned feeling empathy with the patient, particularly with those with prolonged in-hospital stays. All of these positive emotions promoted self-esteem. However, volunteers may feel useless when patients are cared for by their relatives or when poor interaction is possible due to increased workload.
Participants have also experienced some negative emotions, such as anxiety during interactions with disabled patients, anger when they have encountered people who were abandoned in long-term facilities and no longer visited by their families, and guilt when they adopted harsh attitudes towards unpleasant patients. Powerlessness was a frequent emotion linked to death, particularly when children were involved. Similarly, those who volunteered in long-term facilities have reported a feeling of loss and mourning when a patient passed away, because the long stay and the repeated encounters nurtured a deep relationship. This negative impact has often been experienced by participants when they did not develop an appropriate emotional detachment distancing themselves from the issues faced by patients and families: 'I think [volunteering] is a very positive experience. Sometimes it becomes negative [...]. We should wear blinders when we enter the hospital, we should not see or hear, limit the burden and then shake everything off... However, I can't manage to shake off these thoughts when I come back home after seeing young people who suffer and their families suffering even more' (I 6).

Negative emotions were also reported as a consequence of feeling that they do not belong to the care team, the fear of violating patients' privacy or the concern about intruding on nursing activities. According to the majority of the volunteers, simple gestures such as a smile or greeting in the corridor would promote their integration into the care team:

'I think that receiving some attention [...], a half-smile, a more human approach would make you feel part of the group, although you are only a volunteer and, of course, you do not perform nursing, medical or activities of nurses' aides' (I 9).

Volunteers have perceived that the higher the hierarchy, the greater the distance - 'doctors are doctors' - whereas greater interaction was established with nurses' aides, who 'may consider [volunteers] useful for small tasks'. Not feeling part of the care team was often linked to 'feeling underutilized'. Some volunteers would have performed more tasks, including going beyond what was expected from their volunteer role.

\section{Theme 4: Overcoming role difficulties by using different resources and strategies}

The most frequent resource used by volunteers to help deal with the difficulties encountered during their work, was the health-care professionals, particularly nurses; in addition, discussing issues with other volunteers improved their skills for managing difficult situations and strengthening friendships. Among internal resources, wisdom and experience were both considered helpful for dealing with complex situations: 
'When a person feels sick while l'm volunteering or when a patient is agitated and I'm not able to tranquilize him, I immediately think to ask for the help of the staff' (I11).

Participants have reported different strategies for overcoming challenging situations, such as receiving regular 'training', creating supportive relationships, especially within the association of volunteers, showing that members are available to help deal with current and future problems ('When you call me, l'll be there') and in offering empathy ('I act as if I were a patient and give what l'd like to receive').

Different factors promoted regular volunteering. Two participants mentioned older age (for example, retired) and flexible working times (for example, freelance workers) as factors promoting continuous participation in the volunteering programme. The perception of being useful produced a positive impact, as well as the motivations to be a volunteer, which also affected continuity of service. A higher rate of abandonment was perceived among young people 'because they find a job or continue to study' and when initial expectations have been unfulfilled (e.g. people who started volunteering hoping to find a job). All participants reported that the perception of not being obliged to volunteer was a great motivator: indeed, participants revealed that they had abandoned a previous volunteer position when they realized that it was becoming something similar to having a job.

\section{Theme 5: Addressing emerging needs}

There is a need for more clarity regarding the boundaries between professional and volunteer roles. Several participants have asked for a well-defined list of activities they could perform while avoiding tension with the health-care professionals. Some interviewees reported a precise regulation of their role, while others complained of poor information regarding the activities that they could perform:

'We are regulated by a statute, which gives us tips' (I 2).

'I'd like to talk with people telling you what they expect from you and what you should do. [...] I think [the volunteer] should be taught and explained exactly what is expected from them' (I 10).

Participants have reported a perception of 'disconnected association' at two levels: they perceived detachment among the volunteers and cold interpersonal relationships; simultaneously, they also reported communication problems due to wrong or missed information that had increased the distance between the association and volunteers.
Helping feed patients has emerged as the main source of disconnection, although it is beyond the tasks expected of HVs. Some participants thought that feeding 'is dangerous', 'entails responsibility' and 'is beyond the volunteer's tasks'. However, other interviewees believed that feeding 'is a useful activity', 'helps the patient' and 'often the health-care staff does not have the time'. Therefore, some interviewees were willing to perform this task, while others did not want to.

Similarly, participants reported conflicting opinions regarding the training programme. Some of them said that the training they received was better than the training offered by other associations in social and health care. Other interviewees considered the training programme to be insufficient and said they felt abandoned. Most of them perceived a need for training aimed at improving communication and listening skills, non-verbal communication and managing negative feelings. Others would appreciate more manual labs such as making bracelets, which could provide a pretext to approach shy patients. They have recognized the importance of having periodical refreshers on the most frequent health problems (e.g. diabetes) so that they are aware of seemingly trivial requests that may have serious consequences:

'One morning, I found a volunteer with some money in his hand. "Where are you going?", I asked. "I'm going to buy some chocolate for a gentleman." I said: "Have you checked that he is not diabetic?" "Oh, no." "Go back and ask if you can buy the chocolate." Actually, he couldn't eat chocolate. [...] of course, my colleague was told to be careful during the training program [...], but sometimes repetition is useful' (I 8).

Participants have also reported the need for 'adjustment to a changing society' when they entered in long-term facilities and foster homes:

'We started in hospitals, then we moved on to long-term facilities, and now we are increasing in foster homes [...] Society is changing and we have to adjust to people with different needs' (I 1).

\section{DISCUSSION}

Consistent with previous literature, our participants were predominantly female, and there was a wide range in years $(9,10,22,23)$. Retired, employed and student categories were represented (10) and the education level was similar to that documented in available studies $(10$, 22). Having had previous volunteer experience was also common among our participants (22), while the number of years as a volunteer was higher ( 3 to 45 years vs 9 months to 19 years) (10). Differently to the literature (10, 22), witnessing family volunteering examples (22) was less common. 
The emerging themes generally echoed previous studies in EOL care; however, our findings suggest that the reasons for becoming a HV may differ somewhat from those reported in EOL settings (33). Our data mirrored the five motivational factors identified by Claxton-Oldfield and colleagues $(33,34)$ in EOL care, which were altruism, civic responsibility, leisure, personal gain and self-promotion. However, two additional categories emerged: curiosity and fate.

Although the desire to help patients in need was the main motivation, self-serving connotations (e.g. improving self-esteem), being useful for people in need and feeling satisfied or enriched by the experience have also emerged. This 'egoistic dimension' of volunteering has already been suggested in previous studies, which found that a sense of satisfaction from helping others or feeling good were primary motivational factors $(22,35)$. Moreover, having contact with other volunteers also emerged as an important reason for volunteering, as already documented in available studies $(23,36)$, where friendship and camaraderie have been reported as being among the most enjoyable aspects of volunteering. Furthermore, our data showed that volunteering continues to be strongly supported by social-obligation motivations as some participants considered volunteering a way to repay a debt to society in terms of being thankful for a recovery or to set an example (22). If these different expectations are unmet, high rates of abandonment or dissatisfaction among HVs can occur.

Some softs skills, such as communicating, listening and maintaining emotional detachment, have been highlighted as important and can be developed throughout training strategies; moreover, other specific skills, such as prioritization, which requires authorization from the health-care professionals and thereby cooperation, and the capability to provide concrete services, all require training. In designing the training, high consideration should be given to those attributes valued by HVs as important (e.g. ability to reflect), suggesting therefore that different strategies (e.g. distance learning) could be used.

Hospital volunteering emerged as a very complex experience characterized by conflicting emotions as a result of interactions with patients, families and hospital staff in a wide range of settings and situations. HVs reported a negative emotional impact when some critical experience with their patients takes place (e.g. in the case of death), thus suggesting that they also require appropriate training aimed at handling the emotional challenges of their role and at improving their skills to deal with difficult situations.
Moreover, HVs can experience satisfaction, fulfilment and personal growth and, at the same time, the fear of not being considered part of the staff. As in previous studies in the EOL sector $(10,20,23)$, the relationship between volunteers and hospital staff can be critical in ensuring that volunteers feel valued and accepted as members of the patient care team. The need to be recognized for their value, suggests that health-care managers and staff should provide feedback on the services provided by HVs, thus suggesting that health-care workers highly exposed to HVs should also be trained in working with them.

Furthermore, most of our respondents wanted a better definition of their role to avoid tension with the staff. At the hospital level, the boundaries between professional and volunteer roles may be difficult to precisely define since staff shortages require flexibility (37) and create conditions in which the boundaries between appropriate and inappropriate work for volunteers are up for discussion (2). Therefore, health-care managers should carefully consider the consequences of involving HVs as a strategy to save money: it may not only affect the quality of the professional care but also the attitudes and the time spent by health-care professionals with patients to understand their situations. On the other hand, underutilization, as reported by some of our participants, has been documented as prompting the abandonment or discontinuation of volunteering as documented previously $(21,23)$. Health-care systems are facing an increasing demand for informal care in addition to professional health care; thereby, the adoption of policy measures that better value the volunteering workforce can promote the development of new models of care more suitable to the need of current patients (38). Modelling workloads according to the different roles that provide primary patient care (i.e. nurse, nurses' aides, and volunteers) can improve health workforce planning, service efficiency and effectiveness (39-42).

\subsection{Strengths and limitations}

Although this study provided insights into the motivations, experience and challenges of hospital volunteering, the findings should be read in light of some shortcomings. The interviewees participated on a voluntary basis, thereby introducing the possibility that only the most dedicated volunteers were motivated to take part in the study. Indeed, six of the 11 interviewees volunteered more than three hours per week or were volunteer representatives. However, a maximum variation sampling was adopted to improve the credibility of findings; moreover, volunteers from different hospitals and long-term facilities were interviewed. 


\section{CONCLUSIONS}

Hospital volunteering is a valuable and indispensable service capable of ameliorating patients' and family's experience with hospital care as well as helping healthcare professionals to deal with the tremendous increase in patients' needs on a daily basis. With their increased presence at the bedside, HVs will become a second, albeit voluntary, staff behind that formed by health-care professionals, which requires appropriate policies. Policies should be based on (a) a shared vision, between the hospital and the volunteers' association, regarding the role and skills of HVs, aimed at ensuring consistency and quality in the process of care provided; (b) the development of integrated models of care combining different workforces (i.e. professionals and volunteer staff), thus promoting the development of new care models at the bedside; (c) appropriate training of HVs at baseline; (d) individualized continuing education pathways aimed at supporting HVs both emotionally and in the development of the required skills; and also (e) tailored education for health-care staff aimed at helping them to value the service provided by $\mathrm{HVs}$, and to consider HVs' needs and roles.

\section{ACKNOWLEDGEMENTS}

The authors wish to thank the participants to the study and for their contribution as volunteers.

\section{CONFLICTS OF INTEREST}

The authors declare that they have no conflict of interest. The authors alone are responsible for the content and writing of this study.

\section{FUNDING}

This research did not receive any specific grant from funding agencies in the public, commercial, or not-forprofit sectors.

\section{ETHICAL APPROVAL}

Not required.

\section{REFERENCES}

1. Hall M, McKeown L, Roberts K. Caring Canadians, involved Canadians: highlights from the 2000 national survey of giving, volunteering and participating (Catalogue no. 71-542-XPE). Ottawa: Statistics Canada, 2001.

2. Naylor C, Mundle C, Weakes L, Buck D. Volunteering in health and care: securing a sustainable future. Accessed March 23rd, 2016 at: https:// www.kingsfund.org.uk/sites/files/kf/field/field_publication_file/ volunteering-in-health-and-social-care-kingsfund-mar13.pdf.

3. National Institute for Statistics. Attività gratuite a beneficio di altri. Accessed April 14th, 2016 at: http://www. istat.it/it/archivio/129115.

4. Eastaugh SR. Hospital nursing technical efficiency: nurse extenders and enhanced productivity. Hosp Health Serv Adm. 1990;35:561-73.

5. Ayton D, O'Brien P, Treml J, Soh SE, Morello R, Barker A. Nurses' perceptions of preventing falls for patients with dementia in the acute hospital setting. Australas J Ageing. 2017;36:E70-2. doi: 10.1111/ ajag. 12474.

6. Edwards D, Carrier J, Hopkinson J. Assistance at mealtimes in hospital settings and rehabilitation units for patients (>65years) from the perspective of patients, families and healthcare professionals: a mixed methods systematic review. Int J Nurs Stud. 2017;69:100-18. doi: 10.1016/j.ijnurstu.2017.01.013.

7. Nargund $G$. Declining birth rate in developed countries: a radical policy re-think is required. Facts Views Vis Obgyn. 2009;1:191-3.

8. McDonnell A, McKeown J, Keen C, Palfreyman J, Bennett N. Introducing on-ward volunteers to work with patients with dementia. Nurs Older People. 2014;26:28-33. doi: 10.7748/nop2014.04.26.4.28.e572.

9. Sneddon C, Best J. Introduction of mealtime volunteers in a district general hospital. Nurs Stand. 2011;26:37-40. doi: 10.7748/ ns2011.12.26.15.37.c8871.

10. Elliot G, Umeh K. Psychological issues in the voluntary hospice care. $\mathrm{Br}$ J Nurs. 2013;22:377-84. doi: 10.12968/bjon.2013.22.7.377.

11. Hayes N, Ball J. Safe staffing for older people's wards. Accessed May 9th, 2016 at: https://www.rcn.org.uk/_data/assets/pdf_ file/0009/476379/004280.pdf.

12. Palese A, Gonella S, Fontanive A, Guarnier A, Barelli P, Zambiasi P, et al. The degree of satisfaction of in-hospital medical patients with nursing care and predictors of dissatisfaction: findings from a secondary analysis. Scand J Caring Sci. 2017;31:768-78. doi: 10.1111/scs.12396.

13. Nissim R, Regehr M, Rozmovits L, Rodin G. Transforming the experience of cancer care: a qualitative study of a hospital-based volunteer psychosocial support service. Support Care Cancer. 2009;17:801-9. doi: 10.1007/s00520-008-0556-4.

14. Palese A, Ambrosi E, Prosperi L, Guarnier A, Barelli P, Zambiasi P, et al. Missed nursing care and predicting factors in Italian acute medical care settings. Intern Emerg Med. 2015;10:693-702. doi: 10.1007/s11739. 015-1232-6.

15. Galea A, Naylor C, Buck D, Weaks L. Volunteering in acute trusts in England: understanding the scale and impact. Accessed January 20th, 2016 at: www.kingsfund.org.uk/sites/files/kf/field/field_publication_ file/volunteering-in-acute-trusts-in-england-kingsfund-nov13.pdf.

16. Buys DR, Flood KL, Real K, Chang M, Locher JL. Mealtime assistance for hospitalized older adults: a report on the SPOONS volunteer program. J Gerontol Nurs. 2013;9:18-22. doi: 10.3928/00989134-20130614-01.

17. Sales VL, Ashref MS, Lella LK, Huang J, Bhumireddy G, Lefkowitz L, et al. Utilization of trained volunteers decreases 30-day readmissions for heart failure. J Card Fail. 2013;19:842-50. doi: 10.1016/j. cardfail.2013.10.008

18. Monti M, Pamovioi M, Cruciatti F, Castellani L, Romani R. Caratteristiche, motivazioni e attività del volontariato in hospice. Una revisione qualitativa. Italian J Palliat Care. 2007;2:46-53.

19. Hayes N. Valuing volunteers. Nurs Older People. 2014;26:5. doi: 10.7748/nop2014.04.26.4.5.s1 
20. Koivula UM, Karttunen SL. Volunteers in a hospital - opportunity or threat. Exploratory study from Finland. J Health Organ Manag. 2014;28:674-95. doi: 10.1108/JHOM-10-2013-0218.

21. Morris S, Wilmot A, Hill M, Ockenden N, Payne S. A narrative literature review of the contribution of volunteers in end-of-life care services. Palliat Med. 2012;27:428-36. doi: 10.1177/0269216312453608.

22. Zweigenhaft RL, Armstrong J, Quintis F, Riddick A. The motivations and effectiveness of hospital volunteers. J Soc Psychol. 1996;36:25-34. doi: 10.1080/00224545.1996.9923026.

23. Pascuet E, Beauchemin L, Vaillancourt R, Cowin L, Ni A, Rattray M. Volunteer satisfaction and program evaluation at a pediatric hospice. J Palliat Med. 2012;15:567-72. doi: 10.1089/jpm.2011.0426.

24. Richardson A. Life in a hospice: reflections on caring for the dying. London: Radcliffe Publishing, 2007.

25. Tong A, Sainsbury P, Craig J. Consolidated criteria for reporting qualitative research (COREQ): a 32-item checklist for interviews and focus groups. Int J Qual Health Care. 2007;19:349-57. doi: 10.1093/ intqhe/mzm042.

26. Hospital Volunteer Associations [AVO]. The history. Accessed February 15th, 2016 at: http://www.federavo.it/index.php/storia.

27. Graneheim UH, Lundman B. Qualitative content analysis in nursing research: concepts, procedures and measures to achieve trustworthiness. Nurse Educ Today. 2004;24:105-12. doi:10.1016/j. nedt.2003.10.001.

28. Louw S, Watson Todd R, Jimakorn P. Active listening in qualitative research interviews. In: International conference: doing research in applied linguistics. Bangkok, 21-22 April 2011.

29. Sandelowski M, Barroso J. Reading qualitative studies. Int J Qual Methods. 2002;1(1).

30. Polit DF, Beck CT. Essentials of nursing research: appraising evidence for nursing practice. Philadelphia: Wolters Kluwer/Lippincott/Williams \& Wilkins Health, 2014.

31. Komp K, van Kersbergen K, van Tilburg T. Policies for older volunteers: a study of Germany and Italy, 1990-2008. J Aging Stud. 2013;27:443-55. doi: 10.1016/j.jaging.2013.10.003.

32. World Health Organisation. Active ageing: a policy framework. Accessed May 25th, 2017 at: http://whqlibdoc.who.int/hq/2002/ who_nmh_nph_02.8.Pdf.

33. Claxton-Oldfield S, Wasylkiw L, Mark M, Claxton-Oldfield J. The inventory of motivations for hospice palliative care volunteerism: a tool for recruitment and retention. Am J Hosp Palliat Care. 2011;28:3543. doi: 10.1177/1049909110373509.

34. Claxton-Oldfield S, Jefferies J, Fawcett C, Wasylkiw L, ClaxtonOldfield J. Palliative care volunteers: why do they do it? J Palliat Care. 2004;20:78-84.

35. Fitch TR. Characteristics and motivations of college students volunteering for community service. J College Student Personnel. 1987;28:424-31.

36. Field D, Ingleton C, Clark D. The costs of unpaid labour: the use of voluntary staff in the King's Mill Hospice. Health Soc Care Community. 1996;5:198-208. doi: 10.1111/j.1365-2524.1997.tb00114.x.

37. Kuhlmann E, Larsen C. Why we need multi-level health workforce governance: case studies from nursing and medicine in Germany. Health Policy. 2015;119:1636-44. doi: 10.1016/j.healthpol.2015.08.004.

38. Hofmarcher MM, Festl E, Bishop-Tarver L. Health sector employment growth calls for improvements in labor productivity. Health Policy. 2016;120:894-902. doi: 10.1016/j.healthpol.2016.06.001.

39. Barbazza E, Langins M, Kluge H, Tello J. Health workforce governance: processes, tools and actors towards a competent workforce for integrated health services delivery. Health Policy. 2015;119:1645-54. doi: 10.1016/j.healthpol.2015.09.009.

40. Vicarelli G, Pavolini E. Health workforce governance in Italy. Health Policy. 2015;119:1606-12. doi: 10.1016/j.healthpol.2015.09.004.
41. McHugh SM, Tyrrell E, Johnson B, Healy O, Perry IJ, Normand C. Health workforce planning and service expansion during an economic crisis: a case study of the national breast screening programme in Ireland. Health Policy. 2015;119:1593-99. doi: 10.1016/j.healthpol.2015.08.014.

42. Seligardi M, Bassi E, Mongardi M. Nursing sensitive outcomes and staffing: a review on healthcare associated infection. Assist Inferm Ric. 2017;36:172-178. doi: 10.1702/2817.28483. 